\title{
The effect of cold stress on right ventricular function in patients with systemic sclerosis
}

\author{
Skleroderma hastalarında soğuk stresin sağ ventrikülün fonksiyonu üzerine etkisi
}

Mustafa YILMAZTEPE, Meryem AKTOZ, Ersan TATLI, Armağan ALTUN

\begin{abstract}
Objective: Pulmonary hypertension and right heart failure are poor prognostic factors in systemic sclerosis (SSc). The effect of cold stress on pulmonary vasospasm was evaluated in some trials but the results were conflicting. The aim of our study was to determine the effect of cold stress on right ventricular (RV) function.

Materials and Methods: Twenty-four patients with SSc and 24 age and sex-matched healthy controls were enrolled in the study. Transthoracic echocardiography (TTE) was performed to all patients at rest and after peripheral cold exposure. Baseline and after cold stress test TTE results were compared between the groups.

Results: Cold exposure induced changes in particularly right venticular function. Pulmonary acceleration time was significantly shortened in the SSc group $(118.8 \pm 11.7 \mathrm{~ms}$ vs $111.3 \pm 13.7 \mathrm{~ms}$, $\mathrm{P}<0.001)$. Tricuspid annular plane systolic excurison and RV fractional area change were also decreased after cold exposure in the SSc group. $(23.3 \pm 1.6 \mathrm{~mm}$ vs $21.9 \pm 1.9 \mathrm{~mm}, \mathrm{P}<0.001$; $46.3 \pm 5.8$ vs $44.4 \pm 5.8, \mathrm{P}=0.007$, consecutively). Left ventricular (LV) function did not change after cold stress (LV myocardial performance index $(0.42 \pm 0.04$ vs $0.42 \pm 0.05), \mathrm{P}=0.748)$.

Conclusion: Peripheral cold exposure caused a reduction in right ventricular function indicating pulmonary Raynaud's phenomenon as a possible contributing factor.
\end{abstract}

Keywords: Systemic sclerosis, Echocardiography, Tissue Doppler, Right ventricular function

\footnotetext{
Mustafa Yilmaztepe (夰), Meryem Aktoz

Department of Cardiology, School of Medicine, Trakya University, Edirne, Turkey

e-mail:mayilmaztepe@yahoo.com

Ersan Tatl

Department of Cardiology, School of Medicine, Sakarya University, Sakarya, Turkey

Armağan Altun

Department of Cardiology, School of Medicine, Başkent University, Başkent, Turkey
}

Submitted / Gönderilme: 15.05 .2018

Accepted/Kabul:

03.07.2018

\section{ÖZ}

Amaç: Skleroderma (SSc)'da, pulmoner hipertansiyon ve sağ kalp yetersizliği kötü prognoz göstergesidir. SSc'da soğuk stresin pulmoner vazospazm üzerine etkisi ile ilgili çeşitli çalışmalar yapılmış ancak sonuçlar çelişkili çıkmıştır. Bu çalışma ile SSc hastalarında periferik soğuk stresin sağ ventrikül fonksiyonuna etkisini araştırmayı amaçladık.

Gereç ve Yöntem: Yirmi dördü sklerodermalı, 24'ü sağlıklı toplam 48 kişi çalışmaya alındı. Her iki gruba istirahat ve periferik soğuk stres uygulama sonrasında transtorasik ekokardiyografi yapıldı. İstirahat ve soğuk stres sonrası sol ve sağ ventrikül fonksiyonu karşılaştırıldı.

Bulgular: Soğuk stresin özellikle sağ ventrikül fonksiyonunda değişikliğe yol açtığı görüldü. Pulmoner akselerasyon zamanı skleroderma grubunda anlamlı olarak kısaldı $(118.8 \pm 11.7 \mathrm{~ms}$ vs $111.3 \pm 13.7 \mathrm{~ms}, \mathrm{P}<0.001)$. Triküspid anuler düzlem sistolik hareketi ve sağ ventrikül fraksiyonel alan değişimi de soğuk stres ile azaldı (23.3 $\pm 1.6 \mathrm{~mm}$ vs $21.9 \pm 1.9 \mathrm{~mm}, \mathrm{P}<0.001 ; 46.3 \pm 5.8$ vs $44.4 \pm 5.8, \mathrm{P}=$ 0.007 , sirasiyla). Soğuk stres ile sol ventrikül fonksiyonunda değişiklik saptanmadı (sol ventrikül miyokard performans indeksi (0.42 \pm 0.04 vs $0.42 \pm 0.05), \mathrm{P}=0.748)$.

Sonuç: Periferik soğuk stres, sağ ventrikül fonksiyonunda azalmaya sebep olmuştur ve bu da pulmoner Raynaud fenomeninin pulmoner hipertansiyon gelişmesinde etken faktörlerden biri olabileceğini düşündürmektedir.

Anahtar kelimeler: Sistemik skleroz, Ekokardiografi, Doku Doppler, Sağ ventrikül fonksiyonu.

\section{Introduction}

Systemic sclerosis is a multisystemic connective tissue disease that causes vascular damage, and fibrosis in the skin and in the visceral organs [1,2]. Pulmonary and cardiac involvement are common in systemic sclerosis (SSc). Pulmonary hypertension (PHT) and right heart failure are poor prognostic factors. PHT has worse prognosis in patients with SSc than the other types of PHT [3,4]. Early detection of PHT and right ventricular impairment is very important 
because clinical findings become obvious in the advanced stages of the disease. The etiology of PHT in SSc is not well understood. Raynaud's phenomenon is the most common and cardinal feature of SSc seen in about $90 \%$ of patients [5]. It is speculated that, the increased vasospastic response as in Raynaud's phenomenon, can also be seen in pulmonary circulation and can be one of the contributing factors in the development of pulmonary hypertension [6-8].

In the present study, our aim was to investigate the effect of cold stress on right ventricular function using echocardiographic techniques.

\section{Materials and Methods}

Twenty four patients, followed by the Rheumatology Clinic and met the criteria for $\mathrm{SSc}$ as defined by the American College of Rheumatology [9], and 24 age-and sex-matched control subjects were included in the study. Patients with pacemaker implantation, heart failure, right or left bundle branch block, valvular heart disease, with known or suspected coronary heart disease and those using beta-blockers, prostacyclin analogs or ET-1 anatagonists were excluded; $\mathrm{Ca}$ - channel blocking agents were withheld one week before the study. All patients were in sinus rhythm and were asymptomatic in terms of heart failure and pulmonary hypertension. Sixminute walking test was used to estimate the functional status of the patients and transthoracic echocardiographic examination was performed to all patients.

All patients gave written informed consent. The study protocol was approved by the Local Ethics Committee and the study was conducted in accordance with the Declaration of Helsinki.

\section{Echocardiographic Examination}

Transthoracic echocardiographic examinations (Vivid 7 Pro, GE, Horten, Norway, 2-4 Mhz phased-array transducer) were performed by one cardiologist. All the images were recorded digitally and the measurements were done offline by another experienced operator, who was blinded to the patients group. The average of three values were accepted as measurement. The resting echocardiographic examination was performed after the patients had rested for 10 minutes. Data were recorded from the average of three cardiac cycles. Following the baseline examination, cold stress was applied in a similar technique as the previous studies $[10,11]$. The patients' right hand were immersed into cold water $\left(5-10^{\circ} \mathrm{C}\right)$ up to ten minutes if tolerated. The echocardiographic measurements were recorded before the patients took their hands out of the cold water. All of the measurements were performed in accordance with the guidelines [12].

Left ventricle measurements: End-systolic and enddiastolic diameters, septal and posterior wall thickness were measured from parasternal long axis view using M-mode. To calculate biplane left ventricle ejection fraction (LVEF) end-diastolic and end-systolic volumes were measured from apical long axis 4 chamber and 2 chamber views. Left atrium diameter was measured using $\mathrm{M}$-mode from parasternal long view.

Right ventricle measurements: Right ventricle enddiastolic and end-systolic area were measured from apical 4 chamber view to calculate right ventricular fractional area change (RVFAC). Right ventricular free wall thickness was measured from subcostal view. Tricuspid annular plane systolic excursion ( TAPSE ) was measured by M-Mode echocardiography in the apical four chamber view.

Pulsed-wave Doppler measurements: To measure early (E) and late (A) diastolic wave peak velocities, mitral and tricuspid inflow patterns were obtained from an apical four chamber view. Pulmonary acceleration time (PAAT) was measured from right ventricular outflow tract Doppler recordings.

Tissue Doppler measurements: Pulsed-TDI volume samples were gathered from lateral side of LV annulus and free wall side of the RV. Peak systolic (S'), early (E') and late (A') diastolic velocities were obtained from the mitral lateral, and tricuspid free wall annuluses. Isovolumic relaxation time (IVRT), isovolumic contraction time (IVCT) and ejection time (ET) of both ventricles were measured. Left ventricle myocardial perfomance index (LVMPI) and right ventricle myocardial performance index (RVMPI) were calculated using the formula (IVCT+IVRT )/ ET.

Global ventricular function were assessed by myocardial performance index. We used PAAT, for estimation of pulmonary hypertension [13].

Pulmonary acceleration time, IVCT and IVRT, parameteres that associated with time, were adjusted according to heart rate using the formula that Bazett described $(\mathrm{QTc}=\mathrm{QT} / \sqrt{\mathrm{RR}})$ for corrected QT mesurement [14].

Interobserver and intraobserver variability was assessed for PAAT, TAPSE and RV-IVRT from the recorded images of randomly chosen 10 patients. 


\section{Statistical Analysis}

Statistical analysis was performed by using SPSS 22.0. The distribution of variables were evaulated with Kolmogorov Smirnov test. Categorial data were given as counts (percentages) and were analyzed using the Chi-square test. All continuous variables were expressed as mean \pm standard deviation or median (min-max) and analyzed with MannWhitney $U$ test or independent samples $t$ test as appropriate. Baseline and cold stress echocardiographic measurements were compared using Wilcoxon t test. Inter-observer and intra-observer reliability were evaluated using interclass and intraclass correlation coefficients. P values $<0.05$ were accepted to indicate statistical significance.

\section{Results}

\section{Baseline demographic and clinical characteristics}

Demographic data of the subjects were given in Table I. The mean disease duration was $6.5 \pm 4.8$ years (range, 1 - years). There were no differences between groups in terms of age, sex, body mass index (BMI), systolic and diastolic blood pressures, heart rate and six minute walking distance $(\mathrm{P}>$ $0.05)$.

Table I. Clinical and laboratory characteristics of the study population

\begin{tabular}{|l|l|l|l|}
\hline & Controls & Scleroderma & \\
\hline & $(\mathrm{n}=24)$ & $(\mathrm{n}=24)$ & $\mathrm{P}$ \\
\hline Age (years) & $44.3 \pm 8.0$ & $46.8 \pm 12.3$ & 0.160 \\
\hline Female/male, $\mathrm{n} / \mathrm{n}$ & $2 / 22$ & $2 / 22$ & 1 \\
\hline BMI, $\mathrm{kg} / \mathrm{m} 2$ & $27 \pm 4.9$ & $26.2 \pm 4.9$ & 0.535 \\
\hline Heart rate, beats/m & $80.2 \pm 11.0$ & $79.8 \pm 8.8$ & 0.812 \\
\hline SBP, $\mathrm{mmHg}$ & $123.1 \pm 9.4$ & $125.9 \pm 7.8$ & 0.374 \\
\hline DBP, $\mathrm{mmHg}$ & $68.2 \pm 6.4$ & $71.3 \pm 6.5$ & 0.131 \\
\hline Six-minute walking test, $\mathrm{m}$ & $515.4 \pm 37.7$ & $531.8 \pm 57.9$ & 0.725 \\
\hline Disease duration, years & - & $6.5 \pm 4.8$ & - \\
\hline ACE inhibitor, $\mathrm{n}$ & 0 & 4 & 0.489 \\
\hline Oral antidiabetic, $\mathrm{n}$ & 0 & 2 & 0.109 \\
\hline Statin, $\mathrm{n}$ & 0 & 2 & 0.489 \\
\hline
\end{tabular}

ACE: Angiotensin Converting Enzyme, BMI: Body mass index, SBP: Systolic blood pressure, DBP: Diastolic blood pressure.

\section{Echocardiographic Characteristics}

The resting echocardiographic values are given in Table II. LVEF, LV end-diastolic dimension, LV mass index, LA and RA dimensions, LV E/E' and LV S' were similar in both groups. LVMPI was significantly increased in the control group when compared to the SSc group (0.43(0.35-0.54) vs $0.34(0.27-0.41), \mathrm{P}<0.001)$. None of the patients had tricuspid jet velocity more than $2.8 \mathrm{~m} / \mathrm{s}$, but in about $30 \%$ of the study population tricuspid jet could not be visualized.

Table II. Resting echocardiographic characteristics of the study population.

\begin{tabular}{|l|l|l|l|}
\hline & Controls & Scleroderma & \\
\hline & $(\mathrm{n}=24)$ & $(\mathrm{n}=24)$ & $\mathrm{P}$ \\
\hline LVEF, $\%$ & $65.5(58-77)$ & $64.0(56-74)$ & 0.305 \\
\hline LA diameter, mm & $37.0(26-40)$ & $37.0(28-43)$ & 0.487 \\
\hline LVEDD, mm & $46(40-53)$ & $45(38-53)$ & 0.071 \\
\hline Septum thickness, mm & $9(7-10)$ & $10(8-11)$ & 0.138 \\
\hline PW, mm & $9(7-10)$ & $9(7-10)$ & 0.228 \\
\hline LV mass, g/m2 & $73.5(55-104)$ & $74.8(55-117)$ & 0.415 \\
\hline LV E/E' & $5.4(3-9)$ & $6.0(4-16)$ & 0.056 \\
\hline LV MPI & $0.34(0.27-0.41)$ & $0.43(0.35-0.54)$ & $<0.001$ \\
\hline RA diameter, mm & $30.5(25-36)$ & $29.0(27-31)$ & 0.359 \\
\hline RV wall, mm & $3.4(3-4)$ & $4.5(3-6)$ & $<0.001$ \\
\hline SPAP,mmHg & $24.0(20-29)$ & $26.0(24-35)$ & 0.004 \\
\hline RVFAC, $\%$ & $49.0(41-58)$ & $46.5(34-56)$ & $<0.001$ \\
\hline TAPSE, mm & $26.0(22-31)$ & $23(21-26)$ & 0.002 \\
\hline RV IVCT, ms & $48(37-55)$ & $57(48-74)$ & $<0.001$ \\
\hline RV S', cm/s & $15(12-21)$ & $13(10-18)$ & $<0.001$ \\
\hline RV MPI & $0.31(0.26-0.46)$ & $0.42(0.33-0.53)$ & $<0.001$ \\
\hline RV IVRT, ms & $41(37-49)$ & $59(44-85)$ & $<0.001$ \\
\hline PAAT, ms & $140(118-170)$ & $120(96-140)$ & $<0.001$ \\
\hline
\end{tabular}

E: Pulsed wave transmitral early diastolic velocity EF: Ejection fraction, E': Early myocardial diastolic velocity, IVCT: Isovolumetric contraction time, IVRT: Isovolumetric relaxation time, LA: Left atrium, LVEDD: Left ventricle end diastolic diameter, LV:Left ventricle, MPI: Myocardial performance index, PAAT: pulmonary artery acceleration time. PW: Posterior wall, RA: Right atrium, RV: Right ventricle, RVFAC: Right ventricle fractional area change, S': Systolic myocardial velocity, SPAP: Systolic pulmonary artery pressure, TAPSE: Tricuspid annular plane systolic excursion.

Pulmonary acceleration time, RVFAC, TAPSE and Rv S' were all significantly reduced in patients with SSc (120(96140) vs $140(118-170) \mathrm{P}<0.001,46.5(34-56)$ vs 49(41-58), $\mathrm{P}=0.038,23(21-26)$ vs $26(22-31) \mathrm{P}=0.002,13(10-18)$ vs 15(12-21) $\mathrm{P}<0.001$, respectively ). Additionally, IVCT and IVRT values were significantly higher in SSc group ( 57(4874) vs 48(37-55) $\mathrm{P}<0.001$, 59(44-85) vs 41(37-49) $\mathrm{P}<0.001$ ). RV MPI, which shows globally systolic and diastolic dysfunction, was also increased compared to control group (0.42(0.33-0.53) vs 0.31(0.26-0.46), $\mathrm{P}<0.001)$. 


\section{Cold Stress}

Cold stress echocardiographic measurements of the groups were given in Table III. RV systolic function changed in patients in the SSc group after cold stress (RVFAC, TAPSE, IVCT and PAAT), whereas no deterioration of RV function was observed in the control group. Left ventricular function was compared between the control group and SSc group during rest and after cold stress. There were no statistically significant differences in the left ventricular systolic and diastolic function in both groups during cold stress compared with the baseline values.

\section{Reliability}

Intra-observer reliability, as assessed by intra-class correlation coefficients for PAAT, RV IVRT and TAPSE, were respectively 0.96 ( $95 \%$ CI $0.85-0.99$ ), 0.93 ( 95\% CI 0.65-0.98) and 0.97 ( 95\% CI 0.89-0.99). Inter-observer reliability, as assessed by inter-class correlation coefficients for PAAT, RV IVRT and TAPSE, were respectively 0.88 ( 95\% CI $0.60-0.97$ ), 0.86 ( $95 \%$ CI $0.52-0.96$ ) and 0.96 ( 95\% CI 0.86-0.99).

\section{Discussion}

The present study demonstrated that cold stress caused a reduction in right ventricular function indicating cold exposure may cause intermittent pulmonary vasospasm.

Myocardial involvement in SSc is associated with poor prognosis. Biventricular systolic and diastolic impairment has been shown in several studies [14-16]. The mechanism of right and left ventricle involvement can be different. Fibrosis due to collagen deposition is the main mechanism underlying left ventricular dysfunction, but interstitial lung disease and pulmonary hypertension also play an important role in the etiology of right ventricular dysfunction. Subclinical left ventricle dysfunction is not a rare finding [17-19]. In a recently published article of Spethmann et al., subclinical left ventricle impairment was shown using speckle-tracking echocardiography in patients with SSc [20]. Faludi et al., demonstrated that left ventricular diastolic dysfunction was highly prevalent in patients with $\mathrm{SSc}$ and was associated with increased risk of mortality [21]. In parallel with these studies, in the present study we also demonstrated that diastolic and systolic function of

Table III. Comparison of baseline and after cold stress echocardiographic data.

\begin{tabular}{|l|l|l|l|l|l|l|}
\hline & \multicolumn{3}{|l}{ Control $(\mathrm{n}=24)$} & \multicolumn{3}{l|}{ Scleroderma $(\mathrm{n}=24)$} \\
\hline & Rest & Stress & $\mathrm{P}$ & Rest & Stress & $\mathrm{P}$ \\
\hline HR, beats $/ \mathrm{m}$ & $80.2 \pm 11.0$ & $82.3 \pm 11.7$ & $<0.001$ & $79.8 \pm 8.8$ & $81.3 \pm 8.4$ & $<0.001$ \\
\hline PAAT, ms & $142.0 \pm 13.5$ & $141.0 \pm 15.4$ & 0.116 & $118.8 \pm 11.7$ & $111.3 \pm 13.7$ & 0.001 \\
\hline PAATc, ms & $163.4 \pm 15.6$ & $161.9 \pm 17.5$ & 0.544 & $136.6 \pm 13.8$ & $127.9 \pm 16.1$ & $<0.001$ \\
\hline RVFAC, $\%$ & $49.62 \pm 4.8$ & $49.41 \pm 5.1$ & 0.667 & $46.3 \pm 5.8$ & $44.4 \pm 5.8$ & 0.007 \\
\hline TAPSE, mm & $25.75 \pm 2.77$ & $25.70 \pm 2.70$ & 0.909 & $23.3 \pm 1.6$ & $21.9 \pm 1.9$ & $<0.001$ \\
\hline RV S', cm/s & $15.04 \pm 1.75$ & $15.16 \pm 1.55$ & 0.512 & $13.5 \pm 1.8$ & $13.2 \pm 1.7$ & 0.210 \\
\hline RV IVRT, ms & $41.62 \pm 3.3$ & $42.5 \pm 4.5$ & 0.074 & $58.7 \pm 7.8$ & $59.2 \pm 8.6$ & 0.463 \\
\hline RV IVRTc, ms & $47.4 \pm 3.7$ & $47.3 \pm 3.3$ & 0.629 & $67.5 \pm 9.9$ & $67.2 \pm 9.4$ & 0.794 \\
\hline RV IVCT, ms & $47.0 \pm 4.6$ & $47.7 \pm 3.7$ & 0.069 & $58.9 \pm 7.0$ & $61.8 \pm 7.7$ & 0.009 \\
\hline RV IVCTc & $54.3 \pm 7.0$ & $55.4 \pm 6.5$ & 0.110 & $68.2 \pm 10.2$ & $69.1 \pm 9.4$ & 0.217 \\
\hline RV MPI & $0.31 \pm 0.04$ & $0.32 \pm 0.04$ & 0.084 & $0.41 \pm 0.04$ & $0.42 \pm 0.04$ & 0.149 \\
\hline LVEF, $\%$ & $66.3 \pm 4.9$ & $65.8 \pm 4.7$ & 0.175 & $64.9 \pm 4.2$ & $64.4 \pm 4.1$ & 0.327 \\
\hline LVE/E' & $5.64 \pm 1.6$ & $5.74 \pm 1.5$ & 0.886 & $6.9 \pm 2.6$ & $6.9 \pm 2.10$ & 0.548 \\
\hline LV S', cm/s & $8.5 \pm 1.74$ & $8.37 \pm 1.61$ & 0.328 & $8.70 \pm 0.7$ & $8.40 \pm 0.7$ & 0.262 \\
\hline LV MPI & $0.34 \pm 0.04$ & $0.35 \pm 0.04$ & 0.635 & $0.42 \pm 0.04$ & $0.42 \pm 0.05$ & 0.748 \\
\hline
\end{tabular}

E: Pulsed wave transmitral early diastolic velocity, E’: Early myocardial diastolic velocity, HR: Heart rate, IVCT: Isovolumetric contraction time, IVCTc: Isovolumetric contraction time corrected, IVRT: Isovolumetric relaxation time, IVRTc: Isovolumetric relaxation time corrected LV: Left ventricle, MPI: Myocardial performance index, PAAT: Pulmonary artery acceleration time, PAATc: Pulmonary artery acceleration time corrected, RV: Right Ventricle, RVFAC: Right ventricle fractional area change, RV S': Right ventricle systolic myocardial velocity TAPSE: Tricuspid annular plane systolic excursion. 
the left ventricle, as shown by tissue Doppler derived MPI, were decreased compared to the control group.

Right ventricular dysfunction in SSC is associated with poor prognosis and have more prognostic relevance than left ventricular involvement [22]. It is usually due to pulmonary hypertension caused by vascular or interstitial lung disease, additionally ischemia and fibrosis are the other possible factors that cause right ventricular dysfunction. Durmus et al., used speckle-tracking echocardiography and showed right ventricular impairment in SSc patients without pulmonary hypertension [23]. Huez et al., also demonstrated right ventricular diastolic dysfunction and claimed latent pulmonary hypertension as a possible cause [24]. Lindqvist et al., studied right ventricular function in patients with SSc and revealed impaired right ventricular diastolic function and reduced PAAT compared to control group [25]. Based on these results they implied that the cause of right ventricular diastolic impairment might be intermittent pulmonary hypertension.

There is exaggerated response to cold stimuli in SSc. Raynaud's phenomenon (RP) is the cardinal feature of SSc. Similar to RP cold induced vasospasm was demonstrated in renal [26] and coronary arteries in a subgroup of patients [27-30]. Pulmonary hypertension develops in about 10-15 $\%$ of patients with SSc. Repetitive pulmonary vasospasm has been affirmed as a possible mechanism of PHT in SSc. Whilst it is known that cold exposure increases sympathetic activation and systemic vascular resistance, the context of cold induced pulmonary vasospasm has not been proven yet [10]. Increased phosphodiesterase-1C expression and impaired production of prostaglandin I2 and an imbalance between prostaglandin $\mathrm{I} 2$ and thromboxane A2 were shown as the underlying mechanism of cold induced pulmonary vasospasm in patients with RP [31]. The effect of cold exposure on pulmonary circulation has been assessed in several studies with different methods and conflicting results. Several authors reported a reduction in the diffusing capacity of the lung for carbon monoxide (DLCO) [32,33]. They claimed that the decrease in DLCO after cold exposure indicated a reduction in capillary blood volume, suggesting pulmonary vasospasm. However, Lampert et al., also demonstrated a decrease in DLCO but also a reduction in mPAP and pulmonary vascular resistance, and pointed out that intrapulmonary blood redistribution may be the underlying mechanism that caused diminished DLCO [34]. Mukerjee et al., evaluated right ventricular function using cardiac catheterization after 2 minutes of cold stress, and found no differences whereas Sakamoto et al., found an increase in pulmonary hypertension in a subgroup of patients $[11,8]$. In a recently published study, Keir et al., implied pulmonary vasospasm as a possible explanation to worsening symptoms in a subgroup of patients after exposure to cold [6].

Detection of patients with cold induced pulmonary vasospasm and demonstrating the relation with overt pulmonary hypertension may provide a new perspective in the prevention of SSc related pulmonary hypertension. To the best of our knowledge, this is the first study investigating right venticular function after cold stress using echocardiography. In the present study, cold stimuli caused a significant reduction in the parameters of right ventricular systolic function, as TAPSE, RVFAC, IVCT and PAAT, however, there were no changes in left ventricular function after cold stress. One can argue that, whether such a short time of cold exposure can change RV function or not. Pulmonary circulation is a low pressure system and RV thickness is about $1 / 3$ of $L V$, causing RV more sensitive to changes in afterload. Ischemia, fibrosis and pulmonary hypertension are the possible underlying mechanisms for the deterioration in right ventricular function in SSc, however as shown in the present study, solely decrease in RV function after cold stress, cannot be explained by cardiac Raynaud's phenomenon, ischemia or fibrosis. These results indicated that cold induced pulmonary vasospasm may be the cause of changes in RV function, however, further larger scale studies with follow-up are needed to put forth the association between intermittent pulmonary vasospasm and pulmonary hypertension and the underlying patophysiological mechanism.

The first limitation of our study is that we evaluated right ventricular function by transthoracic echocardiography. Despite all efforts, as in all studies based on echocardiography, echocardiograpic measurements have high intra and inter observer variability and we cannot exclude that the significant but small changes found in the present study could be a result of intra-observer variability. Cardiac MRI or right heart catheterization would have given us more objective data but we chose echocardiography since it is a non-invasive, and a low-cost method and can be used for screening. Novel echocardiographic techniques as strain imaging and 3D echocardiographic imaging could also be used, but unfortunately we did not have that opportunity. The second limitation of the present study is that, although the measurements were done offline by a cardiologist who was 
blinded to the patients groups, the operator who performed the echocardiography was not blinded. The other important limitation of our study is small number of patients, and lack of follow-up of patients.

\section{Conclusion}

Cold stress induced pulmonary RP may contribute to the development of PHT. Although, we were able to demonstrate that peripheral cold exposure caused a reduction in isolated right ventricular function by transthoracic echocardiography the lack of right heart catheterization or novel imaging modalities to assess right heart function, prevented us to imply more definitive conclusions. Further studies with larger sample size and follow-up are needed to detect the effects of cold stress on PHT and right heart function.

Conflict of Interest: No conflict of interest was declared by the authors.

\section{References}

1. Mukerjee D, St George D, Coleiro B, et al. Prevalence and outcome in systemic sclerosis associated pulmonary arterial hypertension: application of a registry approach. Ann Rheum Dis 2003;62:1088-93.

2. D'Angelo WA, Fries JF, Masi AT, et al. Pathologic observations in systemic sclerosis (scleroderma). A study of fifty-eight autopsy cases and fifty-eight matched controls. Am J Med 1969;46:428-40.

3. Clements PJ, Furst DE. Heart involvement in systemic sclerosis. Clin Dermatol 1994;12:267-75.

4. Gashouta MA, Humbert M, Hassoun PM. Update in systemic sclerosis-associated pulmonary arterial hypertension. Presse Med 2014;43(10 Pt 2):e293-304. doi: 10.1016/j. lpm.2014.06.007

5. Steen VD. Clinical manifestations of systemic sclerosis. Semin Cutan Med Surg 1998;17:48-54.

6. Keir GJ, Nair A, Giannarou S, et al. Pulmonary vasospasm in systemic sclerosis: noninvasive techniques for detection. Pulm Circ 2015;5:498-505. doi: 10.1086/682221

7. Wise RA, Wigley F, Newball HH, et al. The effect of cold exposure on diffusing capacity in patients with Raynaud's phenomenon. Chest 1982;81:695-8.

8. Sakamoto K, Houya I, Inoue $\mathrm{K}$, et al. An imbalance in plasma prostanoids in patients with Raynaud's phenomenon and pulmonary vasospasm. Eur Respir J 1999;13:137-44.

9. LeRoy EC, Black C, Fleischmajer R, et al. Scleroderma (systemic sclerosis): classification, subsets and pathogenesis. J Rheumatol 1988;15:202-5.

10. Shuck JW, Oetgen WJ, Tesar JT. Pulmonary vascular response during Raynaud's phenomenon in progressive systemic sclerosis. Am J Med 1985;78:221-7.
11. Mukerjee D, Yap LB, Ong V, et al. The myth of pulmonary Raynaud's phenomenon: the contribution of pulmonary arterial vasospasm in patients with systemic sclerosis related pulmonary arterial hypertension. Ann Rheum Dis 2004;63:1627-31. doi: 10.1136/ard.2003.015289

12. Lang RM, Badano LP, Mor-Avi V, et al. Recommendations for cardiac chamber quantification by echocardiography in adults: an update from the American Society of Echocardiography and the European Association of Cardiovascular Imaging. Eur Heart J Cardiovasc Imaging 2015;16:233-70. doi: 10.1093/ehjci/jev014

13. Wang YC, Huang CH, Tu YK. Pulmonary Hypertension and Pulmonary Artery Acceleration Time: A Systematic Review and Meta-Analysis. J Am Soc Echocardiogr 2018;31:201-10. e3. doi: 10.1016/j.echo.2017.10.016

14. Ferri C, Giuggioli D, Sebastiani M, et al. Heart involvement and systemic sclerosis. Lupus 2005;14:702-7.

15. Agoston G, Gargani L, Miglioranza MH, et al. Left atrial dysfunction detected by speckle tracking in patients with systemic sclerosis. Cardiovasc Ultrasound 2014;12:30. doi: 10.1186/1476-7120-12-30

16. Ucar Elalmis O, Cicekcioglu H, Karagoz A, et al. Evaluation of aortic elastic properties in patients with systemic sclerosis. Turk Kardiyol Dern Ars 2014;42:635-42. doi: 10.5543/ tkda.2014.03162

17. Poanta L, Dadu R, Tiboc C, et al. Systolic and diastolic function in patients with systemic sclerosis. Eur J Intern Med 2009;20:378-82. doi: 10.1016/j.ejim.2008.10.011

18. D'Andrea A, Stisi S, Caso P, et al. Associations between left ventricular myocardial involvement and endothelial dysfunction in systemic sclerosis: noninvasive assessment in asymptomatic patients. Echocardiography 2007;24:587-97. doi: 10.1111/j.1540-8175.2007.00436.x

19. Can I, Onat AM, Aytemir K, et al. Detecting subclinical biventricular impairment in scleroderma patients by use of pulsed-wave tissue Doppler imaging. Tex Heart Inst J 2009;36:31-7.

20. Spethmann S, Rieper K, Riemekasten G, et al. Echocardiographic follow-up of patients with systemic sclerosis by 2D speckle tracking echocardiography of the left ventricle. Cardiovasc Ultrasound 2014;12:13. doi: 10.1186/1476-7120-12-13

21. Faludi R, Kolto G, Bartos B, et al. Five-year follow-up of left ventricular diastolic function in systemic sclerosis patients: determinants of mortality and disease progression. Semin Arthritis Rheum 2014;44:220-7. doi: 10.1016/j. semarthrit.2014.04.001

22. Saito M, Wright L, Negishi K, et al. Mechanics and prognostic value of left and right ventricular dysfunction in patients with systemic sclerosis. Eur Heart J Cardiovasc Imaging 2017 doi: 10.1093/ehjci/jex147

23. Durmus E, Sunbul M, Tigen K, et al. Right ventricular and atrial function in systemic sclerosis patients without pulmonary hypertension. Speckle-tracking echocardiographic study. Herz 2015;40:709-15. doi: 10.1007/s00059-014-4113-2

24. Huez S, Roufosse F, Vachiery JL, et al. Isolated right ventricular dysfunction in systemic sclerosis: latent 
pulmonary hypertension? Eur Respir J 2007;30:928-36. doi: 10.1183/09031936.00025607

25. Lindqvist $P$, Caidahl $K$, Neuman-Andersen $G$, et al. Disturbed right ventricular diastolic function in patients with systemic sclerosis: a Doppler tissue imaging study. Chest 2005;128:755-63. doi: 10.1378/chest.128.2.755

26. Cannon PJ, Hassar M, Case DB, et al. The relationship of hypertension and renal failure in scleroderma (progressive systemic sclerosis) to structural and functional abnormalities of the renal cortical circulation. Medicine (Baltimore) 1974;53:1-46.

27. Alexander EL, Firestein GS, Weiss JL, et al. Reversible coldinduced abnormalities in myocardial perfusion and function in systemic sclerosis. Ann Intern Med 1986;105:661-8.

28. Gustafsson R, Mannting F, Kazzam E, et al. Cold-induced reversible myocardial ischaemia in systemic sclerosis. Lancet 1989;2(8661):475-9.

29. Mizuno R, Fujimoto S, Saito Y, et al. Cardiac Raynaud's phenomenon induced by cold provocation as a predictor of long-term left ventricular dysfunction and remodelling in systemic sclerosis: 7-year follow-up study. Eur J Heart Fail 2010;12:268-75. doi: 10.1093/eurjhf/hfp198

30. Quarta S, Galea N, Gigante A, et al. The cardiac magnetic resonance in the diagnosis of cardiac Raynaud phenomenon in a patient with systemic sclerosis: case report and review of literature. Expert Rev Clin Immunol 2016;12:251-5. doi: 10.1586/1744666X.2016.1134320

31. Crosswhite P, Sun Z. Inhibition of phosphodiesterase-1 attenuates cold-induced pulmonary hypertension. Hypertension 2013;61:585-92. doi: 10.1161/ HYPERTENSIONAHA.111.00676

32. Fahey PJ, Utell MJ, Condemi JJ, et al. Raynaud's phenomenon of the lung. Am J Med 1984;76(2):263-9.

33. Barr WG, Fahey PJ. Reduction of pulmonary capillary blood volume following cold exposure in patients with Raynaud's phenomenon. Chest 1988;94:1195-9.

34. Lampert E, Charloux A, Lonsdorfer J, et al. The concept of Raynaud's phenomenon of the lung revisited. Am J Med 1996;101:468-71. 